\title{
Tolerance against ageing in different varieties of Brassica rapa var toria, B. rapa var yellow sarson and $B$. juncea $(\mathrm{L}$.)
}

\author{
Bhim Jyoti $^{1^{*}}$, Rambhajan ${ }^{2}$ and Ushapant ${ }^{3}$ \\ ${ }^{1}$ Department of Seed Science and Technology, College of Forestry, Ranichauri, Tehri-Garhwal-249199 \\ (Uttarakhand), INDIA \\ ${ }^{2 \& 3}$ Department of Genetics and Plant Breeding, Govind Ballabh Pant University of Agricutlture and Technology, \\ Pantnagar-263145 (Uttarakhand), INDIA \\ *Corresponding author. E-mail: bhimjyoti2210@gmail.com
}

Received: October 12, 2016; Revised received: September 11, 2017; Accepted: January 22, 2018

\begin{abstract}
Seed deterioration is a serious problem in developing countries where seeds are stored in places usually without a proper control of humidity and temperature. In this investigation, an effort was made to identify crops as well as varieties of brassica spp. tolerance to ageing and predicting loss of seed viability at regular interval through standard germination under laboratory condition. Analysis of variance showed that mean squares due to crops, ageing periods and crop $\times$ ageing period were significant for \% seed germination. Result revealed that standard germination declined from 95.63 to $37.54 \%$ in toria, 92 to 28.96 in yellow sarson, and 93.79 to $30.92 \%$ in mustard. Similar changes in germination \% were observed at 9 and 12 months of observation. After 6 months, germination \% declined from 95.13 to $35.50 \%$ in toria, 91.87 to $28 \%$ in yellow sarson and 93.33 to $29 \%$ in mustard. Analysis of variance showed significant differences for \%seed germination due to varieties, ageing period and interaction of varieties $\times$ ageing periods. At varietal level AP2, AP3 and AP4 aged seed, Bhawani $(82.66 \%, 68.16 \%$ and $28.17 \%)$ showed higher seed germination \% respectively than other three varieties of toria. In case of yellowsarson and mustard least deterioration for standard germination were observed in B-9 and Kranti respectively. This study indicates that toria seeds have better storability than yeloowsarson and mustard. At varietal level good storage potential was found in Bhawani, B-9 and Krantivariety of toria, yellow sarson and mustard respectively than other three varieties of studied crops.
\end{abstract}

Keywords: Ageing, Brassica juncea, B. rapa var toria, B. rapa var yellow sarson, Standard germination

\section{INTRODUCTION}

High-quality seeds are of great socio-economic significance because seeds provide the majority of our food supply and are important sources of animal and industrial feedstock. High quality seeds could be characterized by maintaining a high germination rate and stable content after storage. Seed germination, seedling emergence and crop establishment are important aspects of canola production, and are the main components of seed/seedling vigour (Devaiahet al., 2007). A major concern of growers is that deterioration of some seed cultivars, leading to loss of vigour, may be undetected before planting.

However seeds gradually deteriorate during prolonged storage and lose viability (McDonald, 1999). In addition, incorrect sowing date or harvesting period under warm and humid conditions can induce seed ageing. This ageing is manifested as reduction in germination percentage and those seeds that do germinate produce weak seedling (Veselova and Veselovsky, 2003). The survival of various seed lots or cultivars may differ when seeds are stored under identical condition. Availability of genetic diversity in the gene pool of cultivated species is keys for a planned genetic improvement and variety development programme. In Brassica, availability of genetic diversity has been one of the major constraints. This is because the sizable collection available in the country does not represent the total spectrum of variability, and that despite recognition of the importance of genetic diversity, it is being eroded because of poor conservation efforts. In case of cultivated plant species, where most of the genetic diversity is confined to the farmer's fields, ex situ conservation of plant genetic resources is the most common method for conservation. Appropriate conditions have to be identified to restrict the deterioration of seed during processing and to prolong the life of the seed in storage. Frequent fluctuation in temperature and relative humidity make the processing and storage of seeds difficult to minimize the loss of viability and change in genetic integrity of the seed, thereby conservation of genetic resources. 
Seed deterioration is a serious problem in developing countries where seeds are stored in places usually without a proper control of humidity and temperature. Temperature and seed moisture content (and/or relative humidity) are the main factors influencing seed deterioration and viability reported by Barton (1964) James (1967) and Roberts (1972). Seed ageing is generally marked by reduction in vigour reported by Trawathaet al., (1995); Agrawal and Sinha (1980); Saxena, 1987 and Gupta and Aneja, 2004). Chhetriet al., (1993)and Arefi and Abdi (2003) reported that viability and rate and capacity of germination declined during ageing. Aged seeds show decreased vigour and produce weak seedlings that are unable to survive once reintroduced into a habitat (Atici et al., 2007). Hsu et al. (2003), Goel et al.(2003), Pukacka and Ratajczak (2007) reported that due to activity of enzymes such as superoxide dismutase, catalase, peroxidase and glutathione reductase were decreased that lowers the respiratory capacity, which in turn lowers both the energy (ATP) and assimilates supply of the germinating seed. Changes in the enzyme macromolecular structure may contribute to their lowered germination efficiency. Loycrajjouet al. (2008) reported that ageing induced deterioration increase the extent of protein oxidation thus inducing loss of functional properties of proteins and enzymes.Ghasemi- Golezaniet al. (2010) reported that decrease in germination percent and other indexes can be related to physiological and biochemical changes during seed aging.

This study has attempted to identify the effect of ageing on germination of rapeseed-mustard seeds over a period of four years, in order to compare tolerance to ageing and predicting loss of seed viability at regular interval through standard germination among three oilseed crops and their varieties.

\section{MATERIALS AND METHODS}

This study was carried out during 2011-12 at GBPUAT, Pantnagar using four varieties of three oilseeds Brassica viz. toria (Brassica rapa Var toria) yellow sarson (Brassica rapa var yellow sarson) and mustard (Brassica juncea L). Varieties of Brassica rapavartoria viz PT-303, PT-507, T-9 and Bhawani varieties of (Brassica rapavar yellow sarson) PPS-1, B
-9, NDYS-2, and Ragani and the varieties of Brassica juncea viz kranti vardan varuna and vardan were used to evaluate the seed viability. For ageing, seeds of all the varieties of brassica spp. were stored in cloth bag for one, two, three and four years under natural conditions and deginated by AP1, AP2, AP3 and AP4 respectively. Standard germination was evaluated after 3 , 69 and 12 month interval.

Seed viability was tested through standard germination $\%$ test. First of all about 25 seeds in four replication from each treatment was treated with the Thiram (Tetramethyl thiramdisulphide) to remove dust particle that adhere on the seed surface. Then after seeds washed with distill water 2 to 3 times and placed for standard germination test was conducted on 100-seed samples of each crop at $20 \pm 1{ }^{\circ} \mathrm{C}$ for $7 \mathrm{~d}$ on moistened Whiteman papers in dark growth chamber. After 7 days, percent germination was calculated on the basis of number of normal seedlings in relation to total number of seeds placed for germination as prescribed in International Rules for Seed Testing (ISTA, 1976). Percent germination was calculated by the following formula:

Germination percentage $=$ Number of normal seedling / Total number of seed X 100

Statistical analysis: Performance of crops over ageing period was determined by using split- split plot design. Performance of varieties over ageing periods was determined by applying two- factor ANOVA. Test of significance were recorded on basis of CD differences at $5 \%$ level of significance.

\section{RESULTS AND DISCUSSION}

Effect of ageing on standard germination in rapeseed-mustard: Analysis of variance showed that mean squares due to crops, ageing periods and crop $\times$ ageing period were significant for $\%$ seed germination (Table -1). Prolonged ageing periods caused reduction in germination \% in all the three Brassica oilseeds. After 3, 6, 9 and 12 month ageing periods, toria showed the highest mean germination \% then mustard and yellow sarson (Fig-1). After 3 month, percent reduction in seed germination from AP1 to AP4 declined from 95.63 to $37.54 \%$ in toria, 92 to 28.96 in yellow sarson, and 93.79 to $30.92 \%$ in mustard. Similar changes in

Table 1. ANOVA for germination \% over ageing periods and crops in Brassica rapavartoria, B. rapavar yellow sarson and B. juncea ( L.).

\begin{tabular}{|c|c|c|c|c|c|}
\hline \multirow{2}{*}{ Source of Variance } & \multirow{2}{*}{$\begin{array}{l}\text { Degree of } \\
\text { freedom }\end{array}$} & \multicolumn{4}{|c|}{ Mean square } \\
\hline & & 3 month & 6 month & 9 month & 12 month \\
\hline Crop & 2 & $510.38 * *$ & $437.53 * *$ & $799.51 * *$ & $971.81 * *$ \\
\hline Error(a) & 6 & 0.39 & 0.229 & 0.434 & 0.145 \\
\hline Varieties & 3 & $59.76 * *$ & 15.93 & 19.01 & 73.82 \\
\hline Error (b) & 24 & 14.55 & 23.29 & 77.85 & 146.38 \\
\hline Ageing periods & 3 & $26032.9 * *$ & $27229.3 * *$ & $31042.0 * *$ & $35328.3^{* *}$ \\
\hline Crops $\times$ AP & 6 & $28.81 * *$ & $24.79 *$ & $37.69 * *$ & $79.42 * *$ \\
\hline Varieties $\times$ AP & 9 & $28.15 * *$ & 6.94 & $28.22 *$ & 29.65 \\
\hline Error(c) & 90 & 4.07 & 6.84 & 9.99 & 15.22 \\
\hline
\end{tabular}

$*$, **, Significant at $5 \%$ and $1 \%$ probability level 


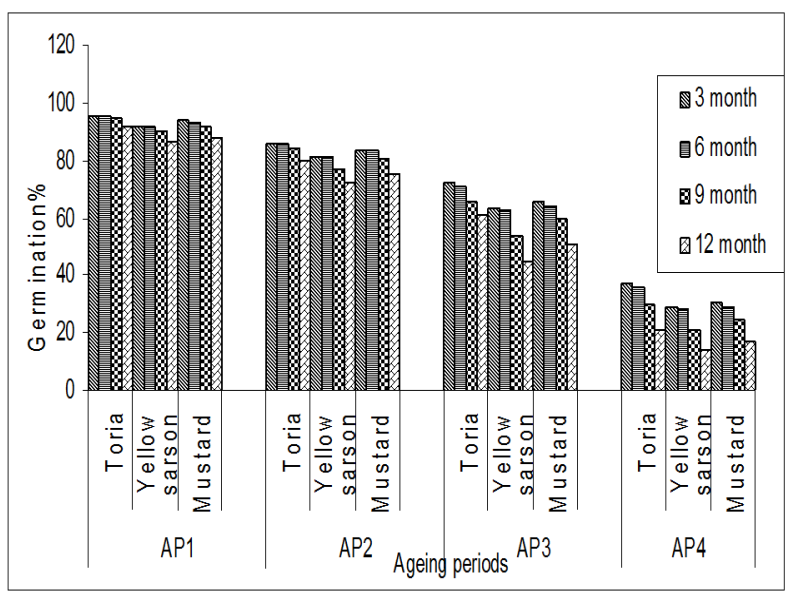

Fig 1. Effect of ageing periods on seed germination in toria, yellow sarson and mustard at different time intervals. Note:AP1- One year aged seed, AP2-Two year aged seeds, AP3Three year aged seeds and AP4-Four year aged seeds.

germination \% were observed at 9 and 12 months of observation.

After 6 months, germination \% declined from 95.13 to $35.50 \%$ in toria, 91.87 to $28 \%$ in yellow sarson and 93.33 to $29 \%$ in mustard. At AP1 stage, yellow sarson $(91.87 \%)$ was statistically at par with mustard $(93.33 \%)$ in \% germination but lower than toria $(95.13 \%)$. At AP2, toria (85.58\%) had significantly higher germination $\%$ followed by mustard $(83.45 \%)$ and yellow sarson $(81.04 \%)$ whereas in AP and AP4 stage, yellow sarson $(62.37 \%$ and $28 \%)$ being statistically at par with mustard (64.42 and 29\%). These results are in agreement with the finding of Mohammadiet al. (2011) who reported that rate of germination percentage depends on the ability of the seeds to resist degradation changes and protection mechanisms, which are specific for each plant species In the present study drastic reduction in mean germination was occurred yellow sarson than toria and mustard. Zhang et al. (2006) reported that seed germination in yellow seeded Brassica napus as compared to brown seeded toria. This could be attributed to high oil and protein content owing to the thinner and transparent testa in yellow seeded $B$. napus and yellow sarson compared with black or brown-seeded varieties of toria. Transparenttesta of yellow-seeded rapeseed lacked some abilities to protectthe embryo against adverse environmental conditions which caused poor storability. Seed coat pigment of brown seeded varieties of toria and mustard may be playing a protective role against seed deterioration during ageing.

Effect of ageing on standard germination in different varieties of toria: Analysis of variance showed that mean squares due to varieties, ageing period and varieties $\times$ ageing period interaction in all three brassicas crop showed significant differences for $\%$ seed germination (Table-2).

The mean value of seed germination (\%) was declined with increase in ageing periods from AP1 to AP4 in all

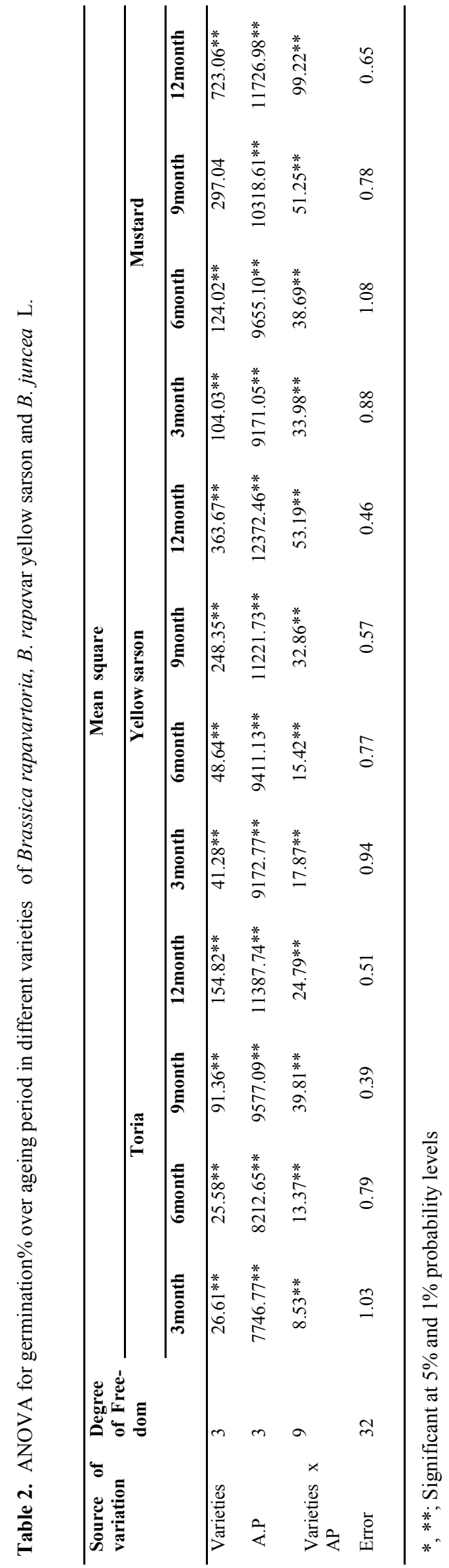


Bhim Jyoti et al. / J. Appl. \& Nat. Sci. 10 (1): 171 - 177 (2018)
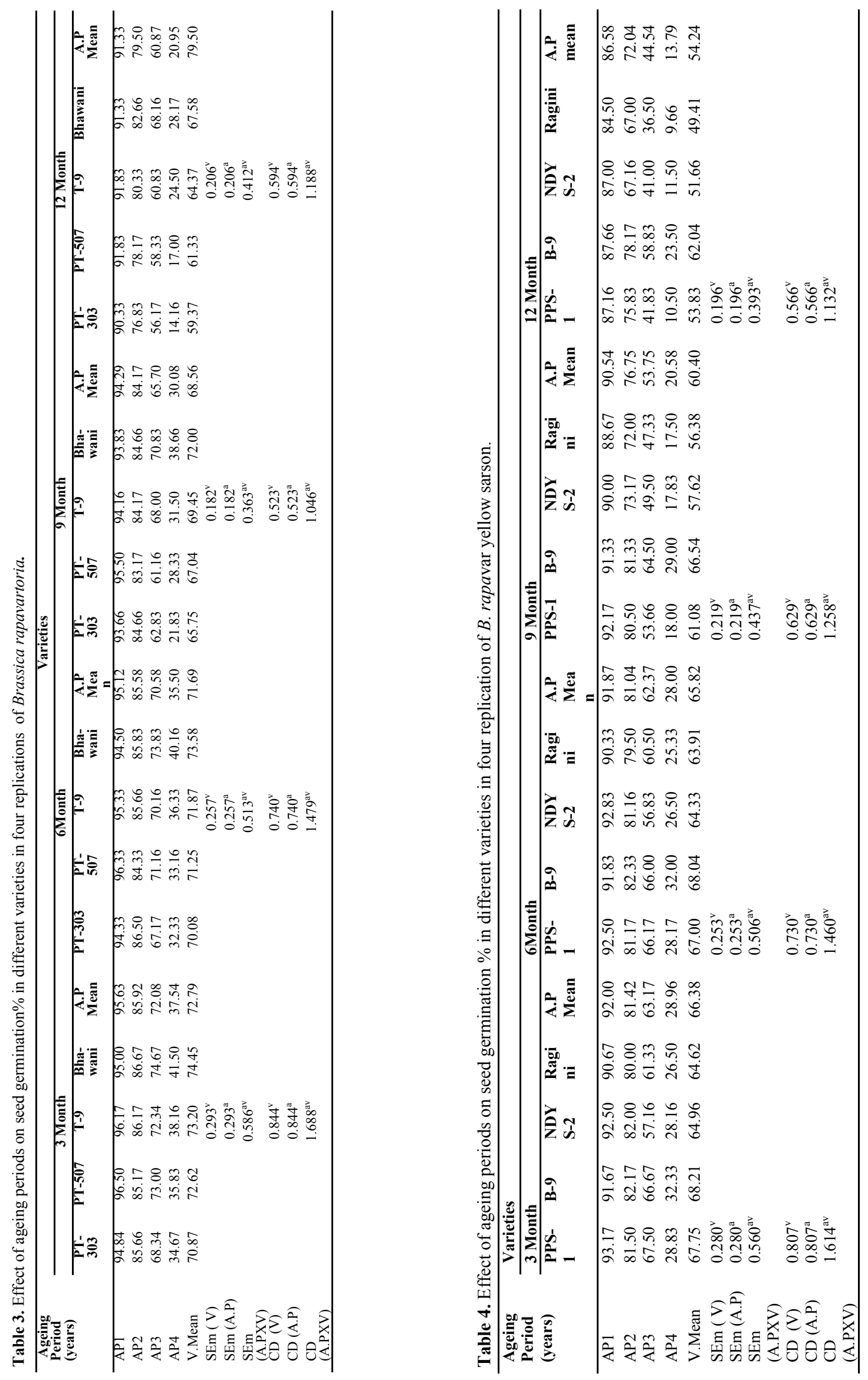


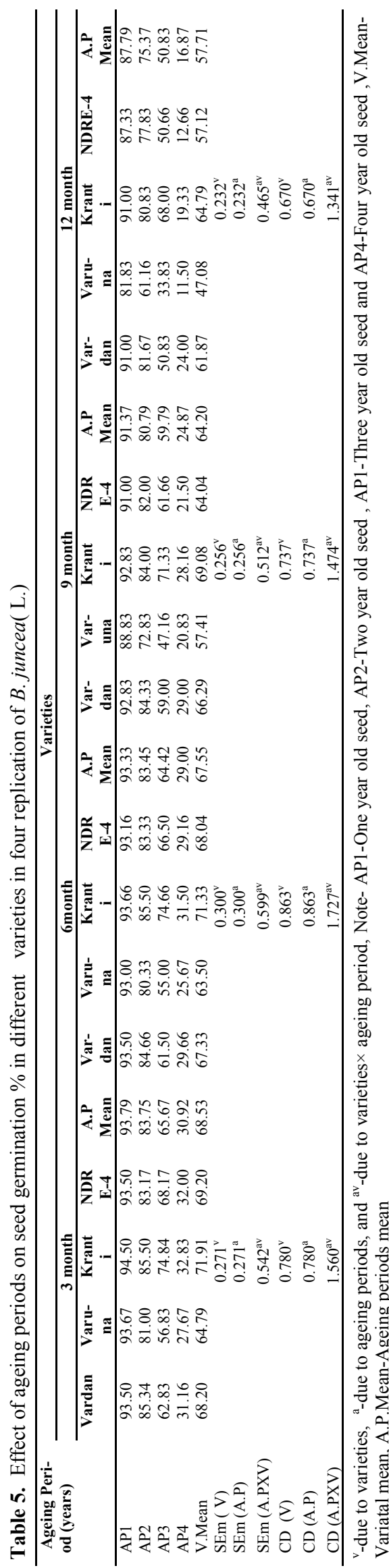

four varieties of toria (Table 3). At 3 month observation, germination (\%) declined from 94.84 to $34.67 \%$ in PT-303, 96.50 to 35.83 in PT-507, 96.17 to 38.16 in T-9 and 95 to $41.50 \%$ in Bhawani. After 6 months, reduction in seed germination was from 94.33 to $32.33 \%$ in PT-303, 96.33 to $33.16 \%$ in PT-507, 95.33 to $36.33 \%$ in $\mathrm{T}-9$ and 94.50 to $40.16 \%$ in Bhawani. Decline in seed germination at 9 month, 93.66 to $21.83 \%$ in PT-303, 95.50 to $28.33 \%$, in PT-507, 94.16 to $31.50 \%$, in $\mathrm{T}-9,93.83$ to $38.66 \%$ in Bhawani respectively. Similarly reduction in 12 months 90.33 to $14.66 \%$ in PT-303, 91.83 to $17 \%$ in PT-507, and 91.83 to $24 \%$ in T-9, and 91.33 to $28.17 \%$ in Bhawani. After 3 months Bhawani (95\%) was found statistically at par with T-9 (96.17\%) and PT-507 (96.50\%) being statistically higher in germination $\%$ than PT-303 in AP1 seeds. At AP2 all varieties were statistically at par with each other whereas in AP3 and AP4, Bhawani (74.67\% and $41.50 \%$ ) showed higher germination $\%$ than other three varieties in which T-9 and PT-507 were at par with each other. After 6 month at AP1 aged seed, Bhawani $(94.50 \%)$ was statistically at par with PT-303 (94.33\%) whereas in AP2 aged seed, PT$303(86.50 \%)$ was statistically at par with T-9 $(85.66 \%)$ and Bhawani $(85.83 \%)$ which expressed higher germination \% than PT-303. In AP4 aged seed, PT-303 (32.33\%) was statistically at par with PT-507 $(33.16 \%)$ which showed lower germination than other two varieties. Similar trend was observed after 9 months interval.

After 12 month observation,at AP1 PT-507 and T-9 $(91.83 \%)$ was statistically at par with Bhawani (91.33\%) expressed higher germination\% than PT-303 $(90.33 \%)$ whereas in AP2, AP3 and AP4 aged seed, Bhawani $(82.66 \%, 68.16 \%$ and $28.17 \%)$ showed higher seed germination \% respectively than other three varieties of toria.

Effect of ageing on standard germination in different varieties of yellow sarson: Germination percentage declined with an increase in ageing periods from AP1 to AP4. After 3 months, it declined from 93.17 to 28.83 in PPS-1, 91.67 to $32.33 \%$ in B-9, 92.50 to $28.16 \%$ in NDYS-2 and 90.67 to 26.50 in Ragini (Table-4). Similar declining trend among varieties was observed after 6 months observations. After 9 month, reduction in seed germination was from 92.17 to $18 \%$ in PPS-1, 91.33 to $29 \%$ in B-9, 90 to $17.83 \%$ in NDYS-2 and 88.67 to $17.50 \%$ in Ragini during the corresponding period. After 12 months, germination $\%$ was reduced from 87.16 to $10.50 \%$ in PPS-1, 87.66 to $23.50 \%$ in B-9, 87 to $11.50 \%$ in NDYS-2 and 84.50 to 9.60 in Ragini. In all four observations, least deterioration was observed in B-9.

Effect of ageing on standard germination in different varieties of mustard: After 3 month decline in germination from AP1 to AP4 was 93.50 to $31.16 \%$ in Vardan, 93.17 to 27.67 in Varuna, 94.50 to 32.83 in 
Kranti and 93.32 to $32 \%$ in NDRE-4(Table-5). Higher mean germination \% was observed in Kranti in all ageing periods at 3 and 6 month interval. However, at 9 and 12 month interval \% germination in Kranti was found similar to Vardan in AP1 and AP2 seeds but Kranti showed significantly high \% germination in AP3 and AP4 seeds. In all ageing periods, Kranti showed lower deterioration whereas rapidly reduction in germination was found in Varuna. Similar declining trend was observed for 12 month observation.

It is quite evident that seed ageing caused reduction in germination percentage in all crops including Brassica crops. Biochemical and physiological changes in seeds during ageing caused reduction in germinability reported by Ghasemi Golezani et al. (2010) and Balešević Tubić et al. (2005) in oilseed Brassica. Balesevic-Tubic (2001) and Malenčić et al. (2003) reported that reduction in germination \% was varied in all three oilseed crops due to genetic factors and seed chemical composition influence the expression of seed deterioration and vigour decline indicated by the differential response of various accessions of species to different types of ageing.

Rapid deterioration in germination \% in oilseed crops has been attributed to be due to their high oil content in the seeds reported by Beratlief and Iliesku (1997) and Sahoo et al. (1998) who noticed that high oil content in seeds is sensitive to autooxidation and increases the content of free fatty acid during ageing period leading to rapid loss in germinability. These processes cause enzyme inactivation, i.e., denaturation of protein and nucleic acids reported by Reuzeau and Cavalie (1995)and Trawatha et al. (1995).

Results of present study showed that seed ageing caused significant reduction in seed germination $\%$ in oilseed Brassicas studied. The magnitude of reduction depended on genetic differences in different varieties. Similar results are reported by Afshari et al., (2009) and Janmohammadi et al. (2008) in Brassica napus. Afshari et al. (2009) and Janmohammadi et al. (2008) was reported that reduction in germination \% during storage has been ascribed to higher leakage of electrolyte and reduced enzyme activity.

Rabiei and Bayat (2009) reported that significant differences for $\%$ germination in different varieties of rapeseed -mustard indicated the existence of genotypic differences for this seed quality trait. Balesevic-Tubic et al. (2011) assumed that variation in germination \%in soybean and sunflower seeds due to genotype differences.

Reduction in seed germination (\%) in different varieties of toria was observed with an increase in ageing period. The germination of seeds stored for 1 to 2 years was greater $(85.17-96.50 \%)$ than the minimum seed certification standard $(85.0 \%)$ and rapid reduction was observed in 3 and 4 year old seeds. Similar findings have been reported by Verma et al. (2003) in Brassica campestris.

Malenčić et al. (2003) and Milošević et al. (1996) sug- gested that seed longevity is genetically determined, and that significant differences exist among cultivars of the same crop in their ability of quality maintenance during storage. Popović et al. (2006) reported that lipid peroxidation and products resulting from these processes lead to DNA denaturisation, prevent translation and protein transcription, and cause oxidation of the most reactive amino acids that may cause decrease in vigour and seed germination. Job et al. (2005) found that inactivation of antioxidant enzymes, seeds lose their ability to stabilize reactive oxygen species thereby enhancing lipids peroxidation and denaturation causes low germination. Ghasemi- Golezaniet al. (2010) reported that decrease in germination percent and other indexes could be related to physiological and biochemical changes during seed aging. They suggest that during aging, decreases plasma membrane sustainability, changes in molecular structure of nucleic acid, decreases in enzyme activities during seed senescence and increases time for fast germination. Kapoor et al. (2010) showed that accelerated aging in cowpea seeds affected all physiological parameters such as germination percentage and vigour index. They found that decrease in seed viability, germination rate and vigour is correlated with biochemical changes (decrease soluble proteins and sugar content) associated with seed aging. The results are also agreement with the finding of Khajeh Hoseini et al. (2003) in soybean.

\section{Conclusion}

On the basis of germination test, the highest mean germination \% was observed in Brassica rapa var toria followed by in B. juncea and B. rapa var yellow sarson. Lowest reduction in germination \% was observed in Bhawani followed by T-9, PT-507 and PT-303. In yellow sarson minimum percent reduction in germination \% was observed in B-9 and maximum in Ragini. Similarly in mustard,Varuna showed high reduction in germination while Kranti showed low reduction. It is significant to mention that results of present study have helped in the better understanding of the effect of ageing periods on seed quality determinants as well as on performance of selected Brassica crops and their varieties studied. Based on the results it can be inferred that during ageing toria showed least reduction in seed germination than other two crops. This study also concluded that seed of toria could be stored for uptotwo years without reduction in germination \% under ambient condition because it had greater standard germination for 1 to 2 years $(85.17-96.50 \%)$ then the minimum seed certification standard $(85.0 \%)$ and on the basis of varieties, Bhawani of toria, B-9 of yellow sarson, and Kranti of mustard showed better storability then other three varieties of studied crops, respectively.

\section{REFERENCES}

Agrawal, P.K and Sinha, S.K. (1980) Response of okra seeds 
(AbelmoschusesculantusL.) of different chronological ages during accelerated ageing and storage. Seed Res., 8: 64-70.

Afshari, RT, Rashidi, S. and Alizadeh, H. (2009) Effects of seed aging on germination characteristics and on catalase and peroxidase activities in two canola cultivars (Brassica napus L.). Iranian Journal of Field Crop Science, 40 (2): 23-29.

Arefi, H.M and Abdi, N. (2003). Study of variation and seed deterioration of Festucaovina germplasm in natural resources genebank. Iranian J. Rangelands and Forests Plant Breeding and Genetic Res.11:105-125.

Atici, Ö., Agar, G. and Battal, P. (2007). Influence of long term storage on plant growth substance levels, germination and seedling growth in legume seeds stored for 37 years. Indian Journal Plant Physiology. 12: 1-5.

Balešević-Tubić $\mathrm{S}$ (2001). The influence og aging process on seed viability and biochemical changes in sunflower seed. PhD Thesis - University of Novi Sad, Novi Sad.

Balesevic-Tubic, S, Malencic, D., Tatic, M and Miladinovic, J. (2005) Influence of ageing process on biochemical changes in sunflower seed. Helia. 28 (42): 107-114.

Barton, L.V. (1964) Seed Preservation and longevity, Pp. 138-157.Inter-social publishers, Inc. New York.

Balesevic-Tubic, S, Tatic, M., Orevic, V., Nikolic, Z and Ukic, V. (2010) Seed viability of oil crops depending on storage conditions. Helia.33 (52): 153-159.

Beratlief, C and Iliescu, H. (1997) Highlights of proper sunflower seed storage. Helia. 20 (26): 121-137.

Chhetri, D.R., Rai, A.S and Bhattacharjee, A. (1993) Chemical manipulation of seed longevity of 4 crop species in an unfavorable storage environment. Seed Sci. Technol. 21:31-44.

Devaiah, S.P., Pan, X.,. Hong, Y., Roth, M., Welti, R. and Wang, X.. (2007).Enhancing seed quality and viability by suppressing phospholipase D in Arabidopsis. The Plant J. 50: 950-957.

Internat. seed testing assiocation.(1976).International rules for seed testing. Seed Science and Technology, 4:3-49

Ghasemi- Golezani, G.K., Khomari, S., Dalili,B.,Mahootchy, A.H and Jedi, A.C.(2010) Effect of seed ageing on field performance of winter oil seed rape. Food Agricultural Environment 8(1): 175- 178.

Goel, A., Goel, A. K. and Sheoran, I. S. (2003). Changes in oxidative stress enzymes during artificial ageing in cotton (Gossypium hirsutum L.) seeds. Plant Physiology. 160:1093-1096.

Gupta, A and Aneja, K. R. (2004) Seed deterioration in soybean varieties during storage- physiological attributes. Seed Res. 32: 26-32.

Hsu, C.C., Chen, C.L. Chen, J.J and Sung, J.M. (2003) Accelerated aging enhanced lipid peroxidation in bitter gourd seeds and effects of priming and hot water soaking treatments. Scientia Horticulturae. 98: 201-12

James, E. (1967) Preservation and seed stocks. Adv Agron 19: $87-106$

Janmohammadi, M., Fallahnezhad, Y., Golshan, M and Mohammadi, H. (2008) Controlled ageing for storability assessment and predicting seedling early growth of canola cultivars (Brassica napus L.). Agricultural and Biological Science 3(5/6): 22-26.

Job, C., Rajjou, L., Lovigny, Y., Belghazi, M. and Job, D. (2005). Patterns of protein oxidation in Arabidopsis seeds and during germination. Plant Physiol., 138:790-802
Kapoor, N., Arya, A., Siddiqui, M.A., Amir, A., Kumar,H. (2010) Seed deterioration in chickpea (Cicer arietinum L.) under accelerated aging. Asian J.Plant Sci., 9(3):158-162.

Khajeh-Hosseini, M., A.A. Powell and I.J. Bingham. (2003) The interaction between salinity stressand seed vigor during germination of soybean seeds. Seed Sci. Technol., 31: 715-725.

Loycrajjou, L.Y., Steven, P.C., Groot, B.M., Job, C. and Job, D.(2008) Proteome wide characterization of seed ageing in arabidopsis. A comparison between artificial and natural ageing. Prot. Pl. Phy. 148: 620-41.

Malenčić, D., Popovic, M and Miladinovic J. (2003) Stress tolerance parameters in different genotypes of soybean. Biology Plantarum. 46: 141-143.

McDonald, M.B. (1999) Seed deterioration physiology repair and assessment. Seed Science and Technology. 27:177-237.

Milosevic M., Cirovic, M., Mihaljev, I. and Dokic, P. (1996). Opste semenarstvo, Feljton, Novi Sad. 148-153.

Mohammadi H, Soltani A., Sadeghipour H.R and Zeinali E (2011). Effect of seed aging on subsequent seed reserve utilization and seedling growth in soybean. Internat. $J$. Plant Prod. 5(1): 65-70.

Pukacka, S.andRatajczak, E. (2007) Age-related biochemical changes during storage of beech (Fagus sylvatica L.) seeds. Seed Science Research. 17: 45-53.

Popović B. (2006). Uticaj $\gamma$ - zračenjanaantioksidantnisistemodabranihgenotipovasojeipojavaoksidativnogstresa. Doktorskadisertacija, Prirodno-matematičkifakultet, Departmanzahemiju, Novi Sad

Rabiei, B. and Bayat, M. (2009) A study of seed germination and seedling growth indices of oilseed rape (Brassica napus $\mathrm{L}$ ) cultivars through seed vigour tests. Journal of Field Crop Sci. 40(2): 13-16.

Reuzeau, C and Cavalie, G. (1995) Activities of free radical processing enzymes in dry sunflower seeds. New Phytol. 130: 59-66.

Roberts, E.H. (1972) Storage environment and control of viability, cytological, genetical and metabolic changes associated with loss of viability. Inc: Viability of seeds. Roberts, E.H.,(ed.) Chapman and Hall, London.

Sahoo, A.K ., Kulkarni, G.N and Vyakaranahal, B.S. (1988) Effect of seed size on yield and quality in bunch groundnut. Seed Res. 16: 136-142.

Saxena, O.P., Singh, G., Pakeeraiah, J and Pandey, N. (1987) Seed deterioration studies in some vegetable seeds. Acta. Hort. 215: 39-44.

Trawatha, S.E., Tekrony, D.M and Hidebrand, D.F. (1995) Relationship of soybean seed quality to fatty acid and C6-Aldehyde levels during storage. Crop Sci .35:14151422.

Verma, S.S., Verma, U and Tomer, R.P.S. (2003) Studies on seed quality parameters in deteriorating seeds in Brassica (Brassica campestris). Seed Sci. Technol. 31(2): 389396.

Veselova, T.V and Veselovasky, V.A. (2003). Investigation of atypical germination changes during accelerated ageing of pea seeds. Seed Sci. Technol. 31: 517-530.

Zhang, X.K., Yang, G.T., Chen, L., Yin, J.M.,Tang, Z.L and Li, J.N. (2006) Physiological differences between yellow-seeded and black-seeded rapeseed (Brassica napus L.) with different testa characteristics during artificial ageing. Seed Sci. Technol. 34(2): 373-381. 